\title{
Subduction in the Western Makran: The historian's contribution
}

\author{
R.M.W. Musson \\ British Geological Survey, West Mains Road, Edinburgh, EH9 3LA, UK; \\ rmwm@bgs.ac.uk \\ Words: 4030 \\ References: 28 \\ Tables: 0 \\ Figures: 3 \\ Running title: Subduction in the Western Makran
}

\begin{abstract}
The Makran subduction zone, which runs along the south-eastern coast of Iran and the southern coast of Pakistan, is a major control on the seismic hazard of the region. While the eastern part of this zone has been active in recent historical times, the western part has not. This could indicate a zone currently locked, or it could be that subduction is occurring aseismically or not at all. Evidence for large thrust activity rests on one event, apparently very large, in 1483. Historical research, especially taking into consideration the political situation in the region at the end of the $15^{\text {th }}$ century, suggests that this 1483 event was a moderate magnitude earthquake in the vicinity of Qeshm Island that has been misassociated with a second, later, earthquake. This interpretation removes from the earthquake catalogue any evidence for major earthquake activity along the Western Makran, and adds weight to the tectonic interpretation that major seismicity has a westerly termination at the Sonne Fault. This presents an interesting example of how a piece of obscure historical information has a significant effect on resolving a question of tectonic interpretation, and with it, influences the estimation of regional seismic hazard, including tsumani hazard in the Indian Ocean.
\end{abstract}


Keywords: Makran, Iran, subduction, great earthquakes, historical seismicity, seismic hazard, tsunami hazard

The Makran coast is an east-west subduction zone running from the Strait of Hormuz to the Ornach-Nal Fault in Pakistan. It is also one of the most inhospitable places on Earth, as Alexander the Great famously found when he attempted to march an army across it in a fit of bravado, on the return leg of his expedition to the Indus Valley, suffering heavy losses. The entire Makran inland was mapped geologically in 19761978; a summary of the results is given in McCall (2002) and references therein. Makran subduction occurred throughout the late Mesozoic and Cenozoic up to the present day; the Cenozoic rocks form a vast accretionary prism. In schematic outlines of the tectonics, the subducting plate is shown as the oceanic eastern extension of the Arabian Plate (e.g. Vita-Finzi 2001, Sattarzadeh et al 2002). The eastern part has been identified as a separate microplate (the Omara Microplate) by Kukowki et al (2000).

The over-riding plate here is dominated by two accreted domains separated by the Sistan suture zone, a deformed forearc basin that records the subduction of an arm of Neotethys beneath the Helmand Block ( ${ }^{\mathrm{TM}}$ engör et al 1988, Byrne et al 1992, Berberian et al 2000). These are the Lut block to the west and the Helmand block to the east (Figure 1); the former being now generally subdivided into the Yazd, Tabas and Lut blocks, and the latter into Helmand and Farah blocks (McCall 1996).

Seismicity is shown in Figure 2 (data taken from the BGS World Seismicity Database, Henni et al 1998). As can be seen, the seismicity associated with the Makran is low compared to other subduction zones, and there is no well-developed Benioff zone apparent. The most notable earthquake shown in Figure 2 is the 28 
November 1945 Gwadur earthquake (8.3 Mw), a tsunamigenic event which killed 4,000 according to Dunbar et al (2002) and about 300 according to Ambraseys and Melville (1982). The earthquake triggered submarine landslides, as evidenced by breaks to submarine cables, local delays in the arrival of most destructive tsunami waves and the erosion of the coastline at Pasni (Byrne et al, 1992). Also associated with this earthquake were the eruption of mud volcanoes and the creation of several temporary islands by the eruption of mud volcanoes offshore (Sondhi 1947). The tsunami was slight on the coast of Muscat, where the earthquake was weakly felt; gossip in the coffee shops the next day attributed the tremors to British testing of atomic weapons (obviously impossible, but such was the grip of the atom bomb on the public imagination at the time - Muscat Intelligence Summary 1945).

A similar earthquake occurring at the western end of the Makran coast would be close to the highly developed area around the UAE and the Straits of Hormuz, and the consequences in terms of damage and loss of life would be more severe than what was experienced in1945, with damage to buildings in the Dibba-Al Khasah region (Wyss and Al-Homoud 2004).

However, from Figure 1 it can be seen that almost all of the shallow Makran seismicity occurs in the eastern part of the zone, and the western part is extremely quiet (the division is close to the Iran/Pakistan border). It appears, therefore, that one of three things is occurring:

1. The western part of the Makran subduction zone is locked pending a great earthquake.

2. The western part of the Makran is subducting almost aseismically.

3. Subduction has virtually ceased in the western Makran.

If the first of these is true, the time-dependent seismic hazard in the area may be quite high; if one of the others is true, great thrust earthquakes $(\mathrm{Mw}>8)$ are not a 
significant regional hazard. There are also important implications for tsunami hazard. If the Western Makran is locked pending a great earthquake, firstly, such an event could be tsunamigenic, and secondly, there is a possibility of the entire Makran rupturing in a single event $\sim 9 \mathrm{Mw}$, producing a major tsunami in the western Indian Ocean.

The purpose of the present study is demonstrate that one piece of evidence in this debate is dependent on an unusual source: political history.

\section{Explaining the lack of great thrust earthquakes in the Western}

\section{Makran}

At a first glance, one might suppose the entire Makran subduction zone to be tectonically homogeneous, as it is often depicted, for example, in Vita-Finzi (2001). McCall (2002) suggests that the overall low seismicity of the Makran compared to other subduction zones is explained by as due to subduction being largely spent; and that subduction is now relatively insignificant compared to crustal shortening in the Zagros. The difference in convergence is accommodated by a major transfer zone running more or less north-south: this is the dextral strike-slip fault zone of the Zendan Fault (Regard et al 2005). GPS evidence shows significant differential movement between Oman and Iran with shortening of the order of $19.5 \mathrm{~mm} \mathrm{yr}^{-1}$ (Masson et al 2007), suggesting that subduction is taking place. Bayer et al. (2006) argue that the lack of earthquakes on the Western Makran can be explained by the fact that this area is characterised by a large amount of unconsolidated and saturated water sediments, which may result in a low frictional coefficient, as the weak sediments lubricate relative plate movement so as to inhibit seismicity. Thus subduction here could be near-aseismic.

What is driving Arabian-Eurasian convergence? Evidently, rifting in the Red Sea and the spreading centre of the Sheba Ridge. However, Kukowski et al (2000) identify a 
further spreading centre at the Murray Ridge (Figure 1). This provides a northward impetus to the easternmost corner of the Arabian plate, divided from the remainder by the Sonne Fault. This can be regarded as a microplate, which is termed the Ormara microplate by Kukowski et al (2000). The Sonne Fault is a sinistral strike slip fault accommodating the differential movement between the Ormara microplate (driven northwards by the Murray Ridge spreading centre close at hand) and the Gulf of Oman (driven only by the distant Sheba Ridge). This provides a good explanation why the Eastern Makran is more seismically active; it is entirely separate from the Western Makran, the Sonne Fault marking the boundary. This also suggests that a single event rupturing both parts of the Makran together is improbable.

However, there is still the question as to why the western part is almost aseismic, rather than just less seismic than the eastern part. This returns to the options cited by Byrne et al (1992): either subduction is aseismic, or the plate boundary is locked pending a great earthquake.

\section{Evidence for and against a great Western Makran earthquake in historical times}

Any geological reasoning as to why subduction should have ceased or be aseismic in the Western Makran would be void if it could be shown that there has in fact been a great earthquake in this part of the subduction front. Byrne et al (1992), consider that such an earthquake occurred an in 1483, affecting the Strait of Hormuz and northeast Oman, with probable epicentre in the Western Makran, though they allow an Eastern Zagros location is also possible.

This event can be traced back to Berberian and Papastamatiou (1978) and Ambraseys and Melville (1982), who give a more precise date of 18 February 1483, a provisional epicentre at $24.9 \mathrm{~N} 57.9 \mathrm{E}$ and an estimated magnitude of $7.7 \mathrm{Mw}$. Ambraseys and Melville (1982) extract their descriptions of the shock in Hormuz from 
the historian Nimdihi; at Jarun (Hormuz) the earthquake damaged or threw down some tall buildings, minarets of mosques, and wind towers of houses. The earthquake was preceded by a long series of foreshocks, starting on 3 November 1482. Ambraseys and Melville (1982) also state that an earthquake was felt in northeast Oman at about the same time. The combination of the reports from Hormuz and Oman and the absence of any reports from Persia suggest, Ambraseys and Melville (1982) argue, that the epicentre must have been to the east and offshore, and therefore most likely in the Western Makran, which would certainly be able of hosting an event of this magnitude. An earthquake in the eastern Zagros capable of strong effects in Oman should have been reported in mainland Persia. Because of the inhospitable and unpopulated nature of the Makran itself, reports near the epicentral area would not be expected. (Places mentioned are shown in Figure 1).

The critical question, which is the main topic of this paper, is whether "about the same time" actually means "at the same time". In other words, was the reported earthquake in Oman that same event, in 1483, that damaged Jarun, or was it some other earthquake? There are plenty of other damaging earthquakes known in the Hormuz-Qeshm Island area, the most recent being those of 27 November 2005 and 10 September 2008 (both $6.0 \mathrm{Mw}$ ). The identification of the 1483 earthquake as a large subduction event depends on the observation that the earthquake also affected north-eastern Oman; this report therefore needs careful inspection. A specific alternative is that the observation from Oman refers to a different earthquake, in 1497, which is described by an Egyptian chronicler as having destroyed an unnamed town; the origin of the information being news reports from Hormuz.

The reference to "north-eastern Oman" actually refers to the town of Qalhat; the spelling of this place name is also given as Calyat, Kalhat and Kilhat, amongst other variants of the name. As will be shown, there are records that Qalhat was damaged or destroyed by an earthquake some time around the end of the $15^{\text {th }}$ Century. If this 
most likely occurred in 1483, it indicates a great earthquake. If it occurred in 1497 or some other year, there is no evidence for a great earthquake. The historical record thus becomes important, and it is necessary not just to read the earthquake descriptions themselves, but to put these reports in their historical context. As will be seen, it is not just the description of the earthquake that is important when the event is assessed.

\section{Qalhat}

From early times Qalhat was evidently an important rendezvous on the Indian Ocean trade routes. It was described in very favourable terms by Marco Polo, who uses the name "Calatu", and also by the geographer Ibn Batuta at the beginning of the $14^{\text {th }} \mathrm{C}$. In 1507 it was visited by the Portuguese explorer Affonso de Albuquerque, who described it as "a city as large as Santarem, badly populated, with many old edifices now destroyed" (Dames 1918). The following year Albuquerque attacked the town, sacked and burnt it. However, when it was visited by Barbosa in 1515 or 1516 it had been resettled, for this writer describes it in the following terms: "... Clarate ... is a large Moorish town of fine, well-built houses, wherein dwell many merchants, wholesale dealers and other gentlemen" (Dames 1918).

It was still occupied in the 1520s. In the historical accounts referred to by Miles (1919) the last mention of it is in 1529. Agius (1999) states that it was razed by Lopo Vaz in 1526, but was occupied in 1534 when Diogo Lopes de Basto was factor. The Turks attacked and captured the town in 1550. Some time shortly after that date the site of the town was abandoned completely. In 1592 it was described as "barren and unpopulated" by Sebastiao de San Pedro (Agius 1999). There are no subsequent mentions of it other than indications on maps, until it was visited by Europeans in the $19^{\text {th }} \mathrm{C}$ (e.g. by Wellsted in 1835), when it was in ruins (Wellsted 1838). Today, but a single ruined structure remains. 
Miles (1919), who was British Representative in Oman 1872-1886, states that, "According to tradition Kilhat was destroyed by an earthquake about four centuries ago ... [but that] Albuquerque in 1507 found it still occupied by a governor sent from Hormuz." Given that Miles was writing at the end of the $19^{\text {th }} \mathrm{C}$ or beginning of the $20^{\text {th }} \mathrm{C}$, "four centuries ago" would place the event around 1500 , or just before Albuquerque arrived. However, elsewhere in the same work, Miles states that the earthquake happened "300 years ago" - at the end of the $16^{\text {th }} \mathrm{C}$.

On the subject of the harbour at Qalhat, Miles (1919) describes “... a deep ravine called the Wady Issa, the mouth of which ... previous to the earthquake formed the harbour, up which vessels could ascend for half a mile ... but it is now so choked that only the smallest boats can enter it ... much impeded by boulders of rock which have fallen from above." Miles visited the site in 1874 and considered the two possibilities that the fall of boulders from the cliffs into the harbour was a result of general erosion or due to dislodgement by an earthquake, and concluded from his observation (albeit that of a layman) that the fall was more likely to have been due to earthquake.

Local Omani sources for the period of concern are more or less confined to Sirhan Ibn Sa'id Ibn Sirhan (Ross 1984) and Salil ibn Razik (Badger 1871). Neither of these have anything to say about any earthquake, and only mention Qalhat during the early period in which it was flourishing. Badger (1871), noting that Qalhat was already in decline in 1507 , attributes this to competition from Muscat, a view supported by all later writers (e.g. Wilkinson 1987).

Modern popular accounts interpret the decline observed by Albuquerque as due to the earthquake, without giving sources. According to Al Shaaibi (1997), “... an earthquake destroyed many of the city's fine buildings at the end of the fourteenth century ...". This earlier date probably derives from the entry in the Encyclopaedia of Islam, which states that Qalhat was severely damaged sometime before the middle of the $14^{\text {th }}$ century (Wilkinson 1974). The basis for this is unknown. 
There are two early sources that do mention an earthquake even if Albuquerque does not, but neither give much more in the way of details. The first of these is Barros (1777), who writes:

O primiero lugar do Reyno de Ormuz a que Affonso d' Alboquerque chegou, foi hum chamado Calyate, que sera de dentro do cabo vinte leguas, o qual em suas ruinas, e edificios mostrava já em outro tempo ser alguma populosa Cidade; e Segundo fama dos naturaes, hum tremor de terra a poz no estado em que Affonso d' Alboquerqe a achou, ....

("The first place in the Kingdom of Ormuz at which Afonso de Albuquerque arrived was called Calyate, twenty leagues past the cape, which in its ruins and buildings showed that in other times it had been a populous city; and, according to the reports of the locals, an earthquake put it in the condition in which Afonso de Albuquerque found it ...")

The other is an anonymous MS in the British Library mentioned by Aubin (1973) with insufficient detail for it to be possible to track the document down. Apparently it mentions both an earthquake and a cyclone, and that works were in progress in 1507 to reconstruct the town. (Aubin also gives a list of relevant sources that do not mention the earthquake.)

Aubin (1973) favours the interpretation that the 1483 earthquake was the one that damaged Qalhat. This conclusion is followed by Berberian and Papastamatiou (1978), Ambraseys and Melville (1982) and also El-Isa (2004). It leads, as seen, to a very large earthquake $(\mathrm{Mw}>7.5)$ in the Gulf of Oman, with reported damage at Hormuz and Qalhat and nowhere else. Even for this period, it is curious that damage should only be reported at such widely separated locations, and not at places like Muscat in between, which was an important trading port at the time. 
An alternative interpretation can be made from the record of an Egyptian chronicler, Ibn lyas, who wrote in April 1497 that news from Hormuz stated that a "certain town" had been destroyed together with its population. Ambraseys and Melville (1982) suggest the town must have been near Hormuz, and speculate that it was most probably Gambrun (today, Bandar Abbas). Agius (1999) however, suggests that the town may have been Qalhat. While this is admittedly conjectural, it is rather convincing.

The critical point lies in the political history of the period. Today, Hormuz Island is mostly only known for giving its name to the Strait of Hormuz. It is a small island of $42 \mathrm{sq} \mathrm{km}$, covered mostly with salt deposits, with no source of drinking water. Despite this, in the $15^{\text {th }}$ century, Hormuz was a powerful independent princedom, thanks to its strategic position aside the trade routes that must perforce pass through the Strait. News from Hormuz would not be very significant in Cairo today, but in the period under consideration, Hormuz was an important regional power.

The princes of Hormuz also had other territorial possessions, of which the most important was Qalhat. When political danger threatened, the ruling family would take refuge in Qalhat. Thus, whatever happened in Qalhat mattered in Hormuz. News of any calamity would flow easily from Qalhat to Hormuz and thence to the outside world (Badger 1871, Miles 1919, Bathurst 1982, Wilkinson 1987).

\section{Discussion}

The hypothesis that the town of Qalhat was damaged in 1497 seems inherently more probable than the proposal that it was damaged in 1483. Firstly, it doesn't require a huge earthquake that caused damage at two places $600 \mathrm{~km}$ apart and nowhere else (with no reports from other trading ports on the Omani coast). Secondly, if repairs were still underway in 1507 , it seems more likely that the earthquake was ten years ago than 24 years ago. Thirdly, a news source in Hormuz in the 1490 s would be 
more likely to pass on news about a Hormuz possession than some Persian town without strong links to Hormuz; and an earthquake that destroyed Gambrun would have strongly affected Hormuz itself (20 km away).

It is relevant to note that in the modern period two earthquakes are reported by ISC from just this part of Oman (see Figure 2). The first occurred on 3 March 1971 (5.0 $\mathrm{mb})$, the second on 28 October $1984(4.7 \mathrm{mb})$. NEIC remarked of the first that it is believed to be the first earthquake instrumentally located on the Arabian Peninsula. The two shocks are located about $50-60 \mathrm{~km}$ south of Qalhat, but the accuracy of the locations, especially the second, is low, given the lack of local stations. According to the Earthquake Monitoring Centre of Oman, the 1971 earthquake was felt at AI Qabel and $\mathrm{Al} \mathrm{Kamel;}$ the magnitude is given as $5.6 \mathrm{ML}$. The same source also lists events in this part of Oman in 1949 and 1968, but not in 1984. It does suggest that there may be an active seismic source in this part of Oman, which makes the possibility that the town of Qalhat was damaged by a local earthquake credible.

Thus it is most likely that the earthquake of 1497 was relatively local to Qalhat and of moderate size.

Furthermore, there is a serious problem with the hypothesis that a great earthquake occurred in 1483. As mentioned, a long series of foreshocks led up to the mainshock. If the epicentre was on the Western Makran, all these foreshocks would have to be very substantial events to be perceptible in Hormuz. This seems highly improbable. In contrast, local seismicity in the Qeshm area has a tendency to exhibit strong foreshock-aftershock activity, as with the events in 1897 and 1902. An earthquake sequence local to Qeshm, with a mainshock magnitude of around $6 \mathrm{Mw}$, better fits the data for 1483 , and is characteristic of general seismic activity in this area. 


\section{Conclusions}

In conclusion, the most likely explanation of the Qalhat story is that the town was damaged by an earthquake in April 1497 with a local epicentre, and a magnitude in the region of $6 \mathrm{Mw}$. This has the corresponding effect of downgrading estimates of the size of the 1483 Hormuz earthquake, from $7.7 \mathrm{Mw}$ to about the same size. Without any further reason to suppose that the 18 February 1483 earthquake was felt in Oman, it becomes entirely a local event to Hormuz, as is strongly suggested anyway by the numerous foreshocks felt in Hormuz. This in turn removes any evidence that the Western Makran has been active in producing large earthquakes in historical times.

If it was the case that the 1483 earthquake was a large subduction event, it would be evident that the absence of more recent seismicity merely indicates that this part of the subduction zone is presently locked. While one cannot prove a negative, there is now no evidence to contradict the hypothesis that existing subduction in the Western Makran is near-aseismic, as proposed by Bayer et al. (2006). This in turn has an effect on seismic hazard analysis. If one believed that the 1483 earthquake was great thrust earthquake in the Western Makran, one would accord a high degree of confidence in modelling the Western Makran as an active subduction feature with a potential for great earthquakes. With the 1483 earthquake downgraded to an earthquake around $6 \mathrm{Mw}$ local to Hormuz, while it is likely that a seismic hazard analyst would still include the Western Makran as an active feature, this would probably be done (assuming a probabilistic approach) with a weighting factor to reflect the uncertainty as to whether this feature is actually capable of large earthquakes. The same applies to tsunami hazard; it is less probable that the Western Makran is a potential source of tsunamis than would be the case if 1483 could have been shown to be a major thrust event; and also, it is considerably less 
probable that there exists any risk of a great earthquake breaking both the Western and Eastern Makran together.

This is an interesting example of how historical research can have an impact on the study of tectonics.

\section{Acknowledgements}

I would like to express my thanks to Professor Derek Agius for helpful discussions.

Dr Joao Fonseca rendered assistance with translations. Thanks also to Phil

Cummins, who prompted me to turn this from a conference presentation at the 2007

IUGG into a written paper, and to Joe McCall and an anonymous reviewer for

suggestions that greatly improved the text. This paper is published with the

permission of the Director of the British Geological Survey (NERC).

\section{References}

Agius, D.A., 1999. Medieval Qalhat: Travellers, dhows and stone anchors in southeast Oman. In: Ray, H.P. (ed), Archaeology of seafaring. Pragati Publications, 173220.

Al-Shaaibi, Y., 1997. The story of Qalhat. World Wide Web Address:

http://www.nwnet.co.uk/qalhat/yaqub/qalhat.htm.

Ambraseys, N.N. \& Melville, C.P., 1982. A history of Persian earthquakes.

Cambridge University Press, Cambridge.

Aubin, J., 1973. Le Royaume d'Ormuz au début du XVIe Siècle. Mare Luso-Indicum, 4, 77-179.

Badger, G.P., 1871. History of the Imams and Seyyids of Oman (by Salil Ibn Razik, trans. G.P. Badger). Hakluyt Society, London.

Barros, J.d., 1777. Da Asia, Decada Segunda. Na Regia Officina Typografica, Lisbon.

Bathurst, R.D., 1982. Maritime trade and imamate government: Two principal themes in the history of Oman to 1728. In: Hopwood, D. (ed), The Arabian Peninsula:

Society and politics. Allen \& Unwin, London, 89-106.

Bayer, R., Chery, J., Tatar, M., Vernant, P., Abbassi, M., Masson, F., Nilforoushan, F., Doerflinger, E., Regard, V. \& Bellier, O., 2006. Active deformation in ZagrosMakran transition zone inferred from GPS measurements. Geophysical Journal International, 165, 373-381. 
Berberian, M. \& Papastamatiou, D., 1978. Khurgu (North Bandar Abbas, Iran) earthquake of March 21, 1977; a preliminary field report and a seismotectonic discussion. Bulletin of the Seismological Society of America, 68, 411-428.

Berberian, M., Jackson, J.A., Qorashi, M., Talebian, M., Khatib, M. \& Priestley, K., 2000. The 1994 Sefidabeh earthquakes in eastern Iran: blind thrusting and bedding plane slip on a growing anticline, and active tectonics of the Sistan suture zone. Geophysical Journal International, 142, 283-299.

Byrne, D., Sykes, S. \& Davis, D., 1992. Great thrust earthquakes and aseismic slip along the plate boundary of the Makran subduction zone. Journal of Geophysical Research, 97, 449-478.

Dames, M.L., 1918. The book of Duarte Barbosa. Hakluyt Society, London.

Dunbar, P.K., Lockridge, P.A. \& Whiteside, L.S., 2002. Catalog of Significant Earthquakes (2150 B.C.-1991 A.D.), National Oceanic and Atmospheric Administration Report.

El-Isa, Z.H., 2004. The seismicity of the Sultanate of Oman and adjacent areas. Seismology and earthquakes in the Arabian Gulf region, 11-12. Sharjah.

Henni, P.H.O., Fyfe, C.J. \& Marrow, P.C., 1998. The BGS World Seismicity Database, BGS Technical Report WL/98/13.

Kukowski, N., Schillhorn, T., Flueh, E. \& Huhn, K., 2000. Newly identified strikeslip plate boundary in the northeastern Arabian Sea. Geology, 28, 355-358.

McCall, G.J.H., 1996. The inner Mesozoic to Eocene ocean of South and Central Iran and the associated microcontinents. Geotectonics (English translation), 29, 490-497.

McCall, G.J.H., 2002. A summary of the geology of the Iranian Makran. In: Clift, P.D., Kroon, D., Gaedicke, C. and Craig, J. (Eds), The tectonic and climatic evolution of the Arabian Sea Region. Special Publications of the Geological Society No 195, Geological Society, 147-204.

Masson, F., Anvari, M., Djamour, Y., Walpersdorf, A., Tavakoli, F., Daignieres, M., Nankali, H. \& Van Gorp, S., 2007. Large-scale velocity field and strain tensor in Iran inferred from GPS measurements: new insight for the present-day deformation pattern within NE Iran. Geophysical Journal International, 170, 436-440.

Miles, S.B., 1919. The countries and tribes of the Persian Gulf. Harrison and Sons, London.

Muscat Intelligence Summary 1945. Public Record Office document R/15/6/359.

Regard, V., Bellier, O., Thomas, J.-C., Bourles, D., Bonnet, S., Abbassi, M., Braucher, R., Shabanian, E., Soleymani, S. \& Feghhi, K., 2005. Cumulative rightlateral fault slip rate across the Zagros-Makran transfer zone: role of the MinabZendan fault system in accommodating Arabia-Eurasia convergence in southeast Iran. Geophysical Journal International, 160, 1-25. 
Ross, E.C., 1984. Annals of Oman to 1728 (by Sirhan Ibn Sa'id Ibn Sirhan, trans. E.C. Ross). Oleander Press, Cambridge.

Sattarzadeh, Y., Cosgrove, J.W. and Vita-Finzi, C., 2002. The geometry of structures in the Zagros cover rocks and its neotectonic implications. In: P.D. Clift, D. Kroon, C. Gaedicke and J. Craig (Editors), The tectonic and climatic evolution of the Arabian Sea Region. Special Publications of the Geological Society No 195. Geological Society, London, 205-218.

engör, A.M.C., Altmer, D., Cin, A., Ustaömer, T. and Hsü, K.J., 1988. Origin and assembly of the tethyside orogenic collage at the expense of Gondwana Land. In: M.G. Audley-Charles and A. Hallam (Eds), Gondwana and Tethys. Special Publications of the Geological Society No 37. Geological Society, Oxford, 119-181.

Sondhi, V.P., 1947. The Makran Earthquake 28th November 1945. Indian Minerals, 1, 147-154.

Vita-Finzi, C., 2001. Neotectonics at the Arabian plate margins. Journal of Structural Geology, 23, 521-530.

Wellsted, J.R., 1838. Travels in Arabia. Murray, London.

Wilkinson, J.C., 1974. Kalhat. In: Bosworth, C.E., Donzel, E.v., Lewis, B. \& Pellat, C. (eds), The encyclopaedia of Islam. Brill, Leiden, 500-501.

Wilkinson, J.C., 1987. The imamate tradition of Oman. Cambridge University Press, Cambridge.

Wyss, M. \& Al-Homoud, A.S., 2004. Scenarios of seismic risk in the United Arab Emirates, an approximate estimate. Natural Hazards, 32, 375-393. 


\section{Figure Captions}

Figure 1

Tectonic features discussed in the text, after McCall (2002). Also shown are places mentioned; solid symbols are those supposedly connected with the 1483 earthquake.

Figure 2

Seismicity of the Makran and surrounding regions. $20^{\text {th }}$ century events mentioned in the text are labelled. 


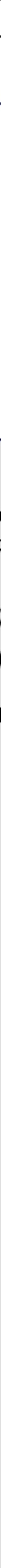




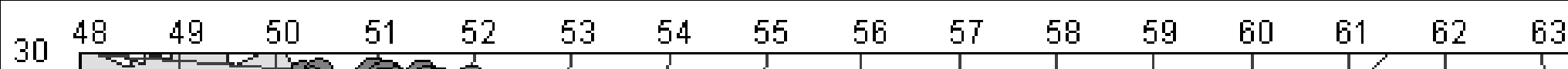

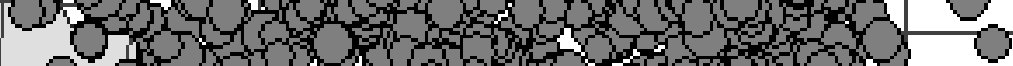

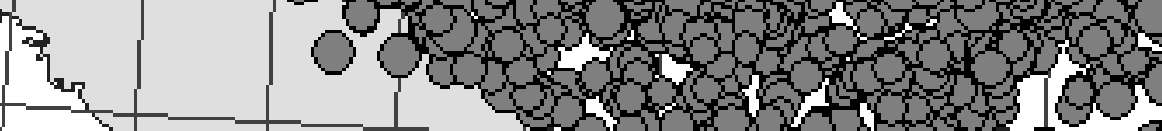

28

26

2

2

2.

21

20

19

18

15 $0 \mathrm{SO} 3 \mathrm{~s}$

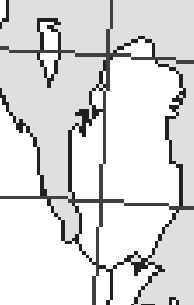

4

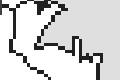

$\circ$

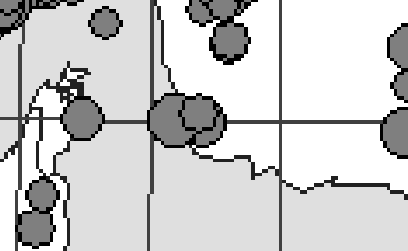

6.80 .0008

0 \%

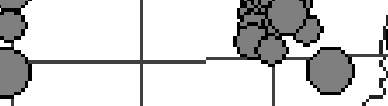

$\infty$

1971/03/03

$1984 / 10 / 28$

$1945 / 11 / 28$
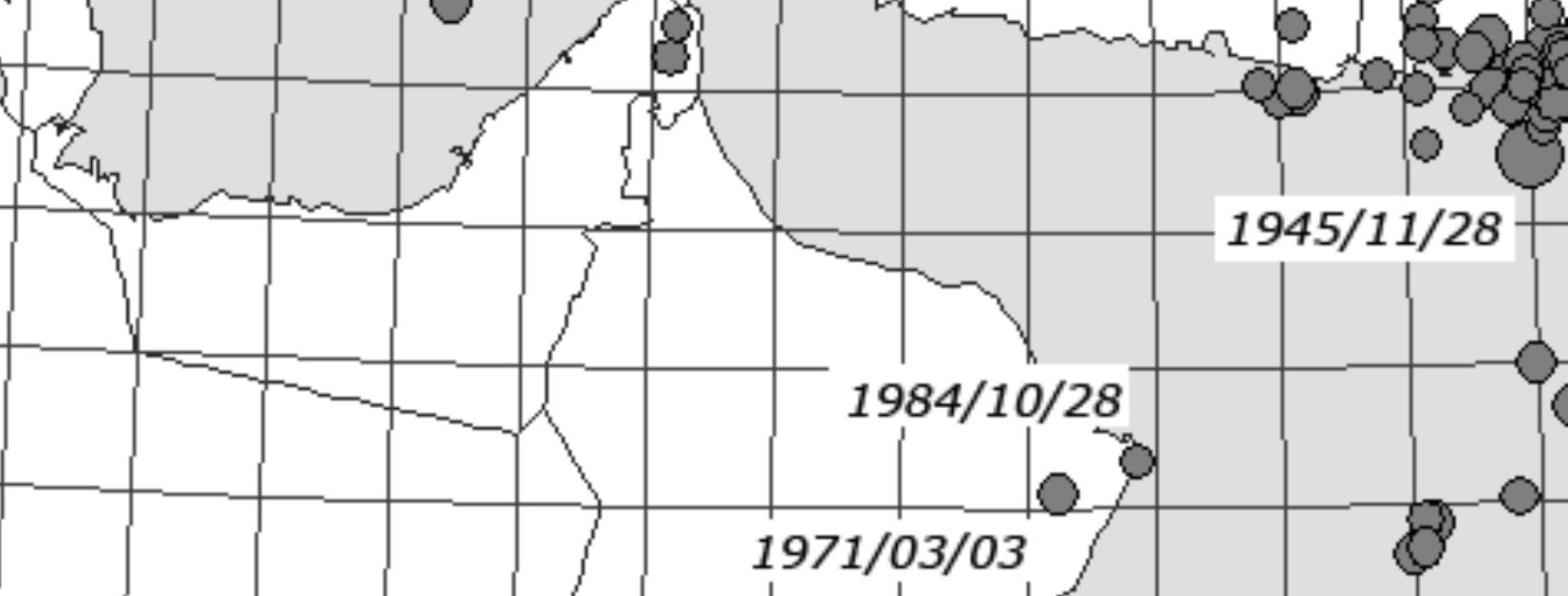

1.

13

$-2000$

8900
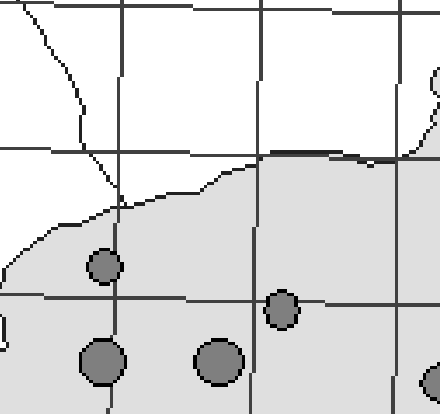

$\zeta$

$\sqrt{2} / 8$

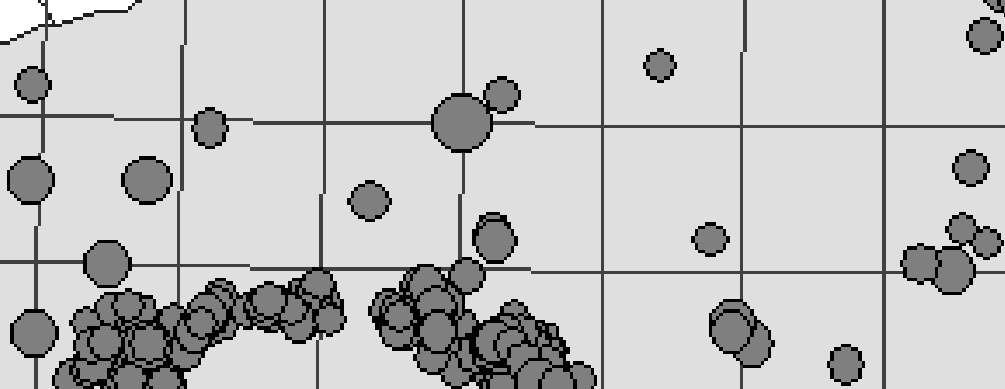

1.

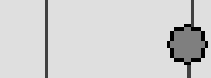

.

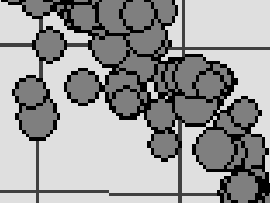

0 